\title{
Effect of Pasteurization Methods on Enzyme Activities, Microbial and Sensory Evaluations in Ready to Serve Watermelon Juice (Citrullus lanatus)
}

Shameena Beegum ${ }^{1 *}$, V.R. Sagar ${ }^{2}$, Abhijit Kar², Eldho Varghese ${ }^{3}$, Surender Singh $^{4}$, M. Neema ${ }^{1}$, Krishna Prakash ${ }^{1}$ and V. Aparna ${ }^{1}$

${ }^{1}$ ICAR - Central Plantation Crops Research Institute, Kasaragod-671124, India

${ }^{2}$ ICAR-Indian Agricultural Research Institute, New Delhi-110012, India

${ }^{3}$ ICAR-Central Marine Fisheries Research Institute, Kochi-682018, Kerala, India

${ }^{4}$ Central University of Haryana, Jant-Pali, Mahendergarh-123031, Haryana, India

*Corresponding author

\section{A B S T R A C T}

\section{Keywords}

Watermelon juice, Enzyme activity, Microbial evaluation, Sensory evaluation

Article Info

Accepted:

20 May 2019

Available Online:

10 June 2019

\begin{abstract}
A comparative evaluation of the use of thermal, microwave and irradiation treatments for pasteurization of ready to serve watermelon juice was undertaken to study their relative impact on residual enzyme (polyphenol oxidase and peroxidase) activities microbial population, and sensorial changes during its refrigerated storage for a period of three months. Pasteurization using thermal and microwave treatments could effectively control the microbial load within the acceptable limit $\left(<1 \log \mathrm{cfu} \mathrm{mL}^{-1}\right)$ over the entire three months of storage. Irradiation treatment of $0.5 \mathrm{kGy}$ resulted in the lowest residual polyphenol oxidase $\left(\mathrm{RA}_{\mathrm{PPO}}\right)$ activity followed by the microwave $(1.56 \mathrm{~W} / \mathrm{ml})$ and thermal treatments. However, maximum reduction in peroxidase activity $\left(R A_{P O D}\right.$ was achieved using thermal and microwave treatments. At the end of the three months storage, watermelon juice pasteurized using microwave energy was sensorially found to be the most acceptable product.
\end{abstract}

\section{Introduction}

Cultivation of watermelon [Citrullus lanatus (Thunb.) var. lanatus] has significantly increased beyond the traditionally confined riverbeds of Yamuna, Ganges and Narmada in North, and Kaveri, Krishna and Godavari in the South because of the increased demand of fresh watermelon and its juice both in the domestic as well as international markets (Aguilo-Aguayo et al., 2010). However, traditional thermal treatments used for the processing of watermelon juice have failed to arrest the detrimental changes in its colour and viscosity mainly because of the catalysis by the intrinsic enzymes like polyphenol oxidase and peroxidase (Rodrigo et al., 2006).

Use of microwave for the pasteurization of milk has been extensively reported (Chiu et al., 1984; Villamiel et al., 1996; Al-Hilphy and Ali, 2013; Rasooly et al., 2014). Ability 
of microwaves in reducing thermal exposure time, pathogenic microbial load while simultaneously retaining the quality and acceptability of the treated produce has invoked tremendous interest for its application in the beverage industry (Nikdel et al., 1992; Tajchakavit et al., 1997; Canumir et al., 2002; Igual et al., 2010). Recently this technology has been found effective in preserving the liquid egg white (Lotfian et al., 2014)

Irradiation is one among the non-thermal processing method involves the exposure of food to ionizing energy for the purpose of shelf life extension. Irradiation doses of upto $10 \mathrm{kGy}$ or more have been approved to be safe for application into food products by World Health Organization (WHO, 1999). Earlier reports suggest the application of irradiation for inactivation of enzymes and microbes (Eissa et al., 2014; Alighourchi et al., 2014)

Review suggesting non-availability of a standard thermal treatment for the pasteurization of watermelon juice on one hand and the availability of alternative nonthermal technologies which could be effectively used for pasteurization led to this study to understand the effect of these available alternative techniques like microwave application and irradiation vis-àvis traditional thermal processing in reducing the change in colour, enzyme activities and microbial load, at the same time achieving better sensorial quality.

\section{Materials and Methods}

\section{Sample preparation}

Fresh watermelon fruits (var. Sugar baby) of uniform size were procured from the local market and stored under room temperature till further use. Fruits were cut, flesh separated, seeds separated from the pulp and juice extracted from the de-seeded pulp. The extracted juice was subsequently clarified using a double-layered muslin cloth, tested for physicochemical parameters (titratable acidity- AOAC, 2002; Total Soluble Solids (TSS); organic acids-HPLC method; ascorbic acid- AOAC, 2002 and lycopene- with a slight modification to the method described by Ranganna, 2007) ingredients (sugar; acid regulator E-296; preservative E-211; and stabilizer E-440) added and thoroughly mixed and bottled.

Pasteurization Treatments:

The bottles were pasteurized as follows:

Irradiation treatment of $0.5 \mathrm{kGy}$ was given using Co-60 irradiator $(12000 \mathrm{Ci}$, with $5000 \mathrm{cc}$ capacity, from BARC, Mumbai) available at ICAR-IARI.

Microwave treatment $(1.56 \mathrm{~W} / \mathrm{ml})$ was given using a domestic microwave oven (model: WP700L17-3, Padmini make, India).

Thermal pasteurization $\left(72^{\circ} \mathrm{C}\right.$ for $\left.20 \mathrm{~s}\right)$ was given using a precision water bath.

Each of the above treatment conditions have been finalized by conducting preliminary experimentation involving different experimental variables. Untreated juice was used as control. Each of the treatments was studied with five replications using a full factorial design. Pasteurized juice samples were stored under refrigerated conditions $\left(4 \pm 2^{\circ} \mathrm{C}\right)$ for three months. Samples were analysed for enzyme activity at 10 days intervals. Microbial and sensory evaluation was carried out at 30 days intervals.

\section{Enzyme activity}

$5 \mathrm{ml}$ of juice sample was added to $5 \mathrm{ml} 0.1 \mathrm{M}$ phosphate buffer ( $\mathrm{pH} 7$ ) containing $5 \mathrm{~g}$ of 
polyvinyl pyrrolidone using magnetic stirrer for $15 \mathrm{~min}$. The homogenate centrifuged (Sigma, 3-18K) at 2,500 rpm for $20 \mathrm{~min}$., supernatant filtered through Whatman No.42 filter paper and the filtrate collected for enzyme analysis. PPO activity was determined using spectrophotometric method based on an initial rate of increase in absorbance at $410 \mathrm{~nm}$ (Soliva et al., 2001). Phosphate buffer solution $\mathrm{pH} 7(0.1 \mathrm{M}, 1.95$ $\mathrm{ml}), 1 \mathrm{~mL}$ of $0.1 \mathrm{M}$ catechol as a substrate and $50 \mu \mathrm{l}$ of the enzyme extract were pipetted into a test tube and mixed thoroughly. Then the mixture was rapidly transferred to a $1-\mathrm{cm}$ path length cuvette. The absorbance at 410 $\mathrm{nm}$ was recorded continuously at $25^{\circ} \mathrm{C}$ for 5 min using ultraviolet-visible spectrophotometer (JASCO-V- 690).

Peroxidase (POD) activity was assayed spectrophotometrically at $470 \mathrm{~nm}$ using guaiacol as a phenolic substrate along with hydrogen peroxide (Diaz et al., 2001). The reaction mixture contained $0.15 \mathrm{ml}$ of $4 \%$ (v/v) guaiacol, $0.15 \mathrm{ml}$ of $1 \%(\mathrm{v} / \mathrm{v}) \mathrm{H}_{2} \mathrm{O}_{2}$, and $2.66 \mathrm{ml}$ of $0.1 \mathrm{M}$ phosphate buffer $\mathrm{pH} 7$ and $40 \mu 1$ of the enzyme extract. The blank sample contained the same mixture solution without the enzyme extract enzyme extract were pipetted into a test tube and mixed thoroughly.

Then the mixture was rapidly transferred to a $1-\mathrm{cm}$ path length cuvette. The absorbance at $470 \mathrm{~nm}$ was recorded continuously at $25^{\circ} \mathrm{C}$ for $5 \mathrm{~min}$.

The residual activities of PPO and POD were calculated according to the following equation,

Enzyme activity in treated

(Pasteurized) juice sample

Residual activity = ----------------------- X100

Enzyme activity in control

(Unpasteurized) juice sample

\section{Microbial evaluation}

The juice samples were analysed for the population of total aerobic bacteria, yeast and mould and total coliforms using Standard Plate Count Agar (SPCA), Martin Rose Bengal Agar and Eosin Methylene Blue Agar (EMB) media respectively. Serial dilution technique with spread plating was used for enumeration of microbial population in the pasteurized juice and incubated at $30^{\circ} \mathrm{C}$ for 24 to $48 \mathrm{~h}$ for both fungi and bacteria and at $37^{\circ} \mathrm{C}$ for total coliforms. Results were expressed in terms of colony forming unit (cfu) per $\mathrm{ml}$ of juice sample.

\section{Sensory evaluation}

The sensory evaluation was conducted primarily to assess the flavour along with other characters like appearance, colour, taste, and overall acceptability of different treatments. A sensory panel of 10-untrained members was used to evaluate various sensory attributes using a 9-point hedonic scale ( $1=$ dislike extremely, $9=$ like extremely).

\section{Analysis of results}

Results were analysed for statistical significance by factorial analysis of Variance (ANOVA) and means were compared using Tukey's Studentized Range (HSD) Test using SAS-9.3 Software. The analysis of sensory evaluation was done by the non-parametric method Friedman mean rank for the comparison of the score assigned by the sensory panel. Chi-square analysis was done and treatments and storage period was compared using asymptotic significance (Asymp. Sig) level $(\mathrm{p}<0.05)$.

\section{Results and Discussion}

The extracted watermelon juice was analyzed for $\mathrm{pH}$, titratable acidity, organic acid, total 
soluble solids, ascorbic acid and lycopene and the corresponding values were 5.64 \pm 0.2 , $0.08 \pm 0.01 \%$ (as malic acid), $3.38 \mathrm{mg}$ citric acid $/ \mathrm{ml}$ juice, $0.25 \mathrm{mg}$ citric acid $/ \mathrm{ml}$ juice, $8.9 \pm 0.46^{\circ} \mathrm{B}, \quad 8.00 \pm 0.17 \mathrm{mg}$ ascorbic $\mathrm{acid} / 100 \mathrm{ml}$ juice, and $5.7 \pm 0.13 \mathrm{mg}$ lycopene $/ 100 \mathrm{~g}$ juice respectively. The ready to serve juice prepared out of extracted watermelon juice had $4.4 \pm 0.3 \mathrm{pH}, 0.3 \pm 0.02 \%$ titratable acidity (as malic acid), $12.2 \pm 0.2^{\circ} \mathrm{B}$ total soluble solids, $0.2 \%$ pectin and $0.1 \%$ sodium benzoate.

\section{Residual PPO}

Poly phenol Oxidase (PPO) residual activity detected in the juice samples immediately after the thermal, microwave and irradiation was $70.77 \%, \quad 31.36 \%$ and $34.17 \%$ respectively. The effect of pasteurization on residual PPO activity is shown in Figure 1. Watermelon juice having the most delicate flavour compounds showed an irregular trend in residual PPO irrespective of the method of pasteurization. It was clear from the data that thermal pasteurization could not inactivate the PPO activity in watermelon juice. Here, a steady increase in the residual activity was observed till 80th day. Even a maximum activity upto $93.98 \%$ was seen from the $70^{\text {th }}$ day's observation. Liu et al., (2012) observed PPO residual activity of $49.1 \%$ immediately after thermal pasteurization at $95{ }^{\circ} \mathrm{C}$ for 1 min. The PPO activity in strawberry puree from two cultivars was highly resistant to thermal inactivation even at temperature as high as $100^{\circ} \mathrm{C}$ Terefe et al., (2010). But, surprisingly Igual et al., (2010) obtained 94\% PPO inactivation through conventional pasteurization than microwave pasteurization $(88 \%)$ in grape fruit juice. Earlier reports suggest that non thermal pasteurization techniques like irradiation, Pulsed Electric Field (PEF) and High Pressure carbon dioxide (HPCD) could be completely inactivate PPO activity (Ertugay et al., 2013; Liu et al.,
2012). But none of the methods could completely inactivate the enzyme activity.

It was seen from the present study that irradiation at $0.5 \mathrm{kGy}$ was the most effective method to reduce the PPO activity. Even the mean value for the entire three months storage period was $32 \%$. Till 70th day it could maintain the lowest activity of $20.24 \%$ but, there was a sudden increase in the activity after 80 days of storage. Still it showed only $32.3 \%$ activity at the end of storage ( $90^{\text {th }}$ day).

Hanotel et al., (1995) observed 30\% inhibition of polyphenol oxidase and peroxidase activities after irradiation in cut witloof chicory. However, the efficacies of inhibition to PPO activity depend on the irradiation dose. Eissa et al., (2014) observed that inhibition to PPO activity increased as the irradiation dose from $1 \mathrm{kGy}$ to $5 \mathrm{kGy}$ with $91 \%$. But, concerning the nutritional and biochemical quality of fruit juice the irradiation dose was limited to $0.5 \mathrm{kGy}$ in the present study. The result of this study also revealed that microwave pasteurization is also effective in reducing the residual PPO activity. The initial residual activity of microwave pasteurized juice samples were $31.36 \%$ which was later on increased to $87.92 \%$ on the $70^{\text {th }}$ day then fallen down to $62.28 \%$ on the $90^{\text {th }}$ day. The report of Math et al., (2014) strongly supports this finding.

\section{Residual POD}

The graphical representation of the result of pasteurization methods on residual peroxidase (POD) in watermelon juice during 90 days of storage at $4 \pm 2{ }^{\circ} \mathrm{C}$ is presented in Figure 2. One interesting finding was the effectiveness of thermal was not immediate. The observed residual activity immediately after the three sets of pasteurization was $52 \%, 12 \%$ and $4 \%$ for thermal, microwave and irradiation respectively. 
Fig.1 Effect of pasteurization methods on residual polyphenol oxidase (RAPPO) activity during storage $(\%)$ at $4 \pm 2{ }^{\circ} \mathrm{C}$

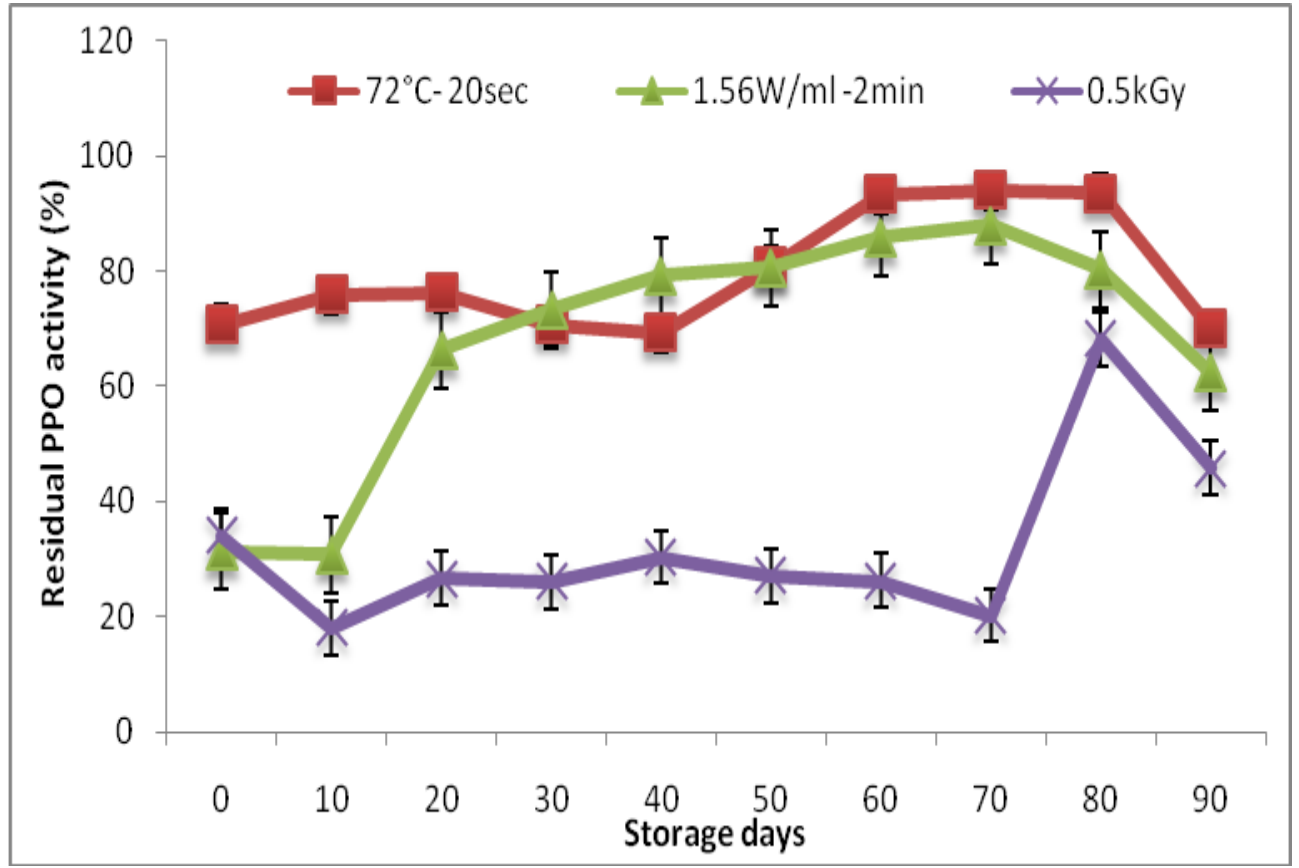

Fig.2 Effect of pasteurization methods on residual peroxidase (RAPOD) activity during storage $(\%)$ at $4 \pm 2{ }^{\circ} \mathrm{C}$

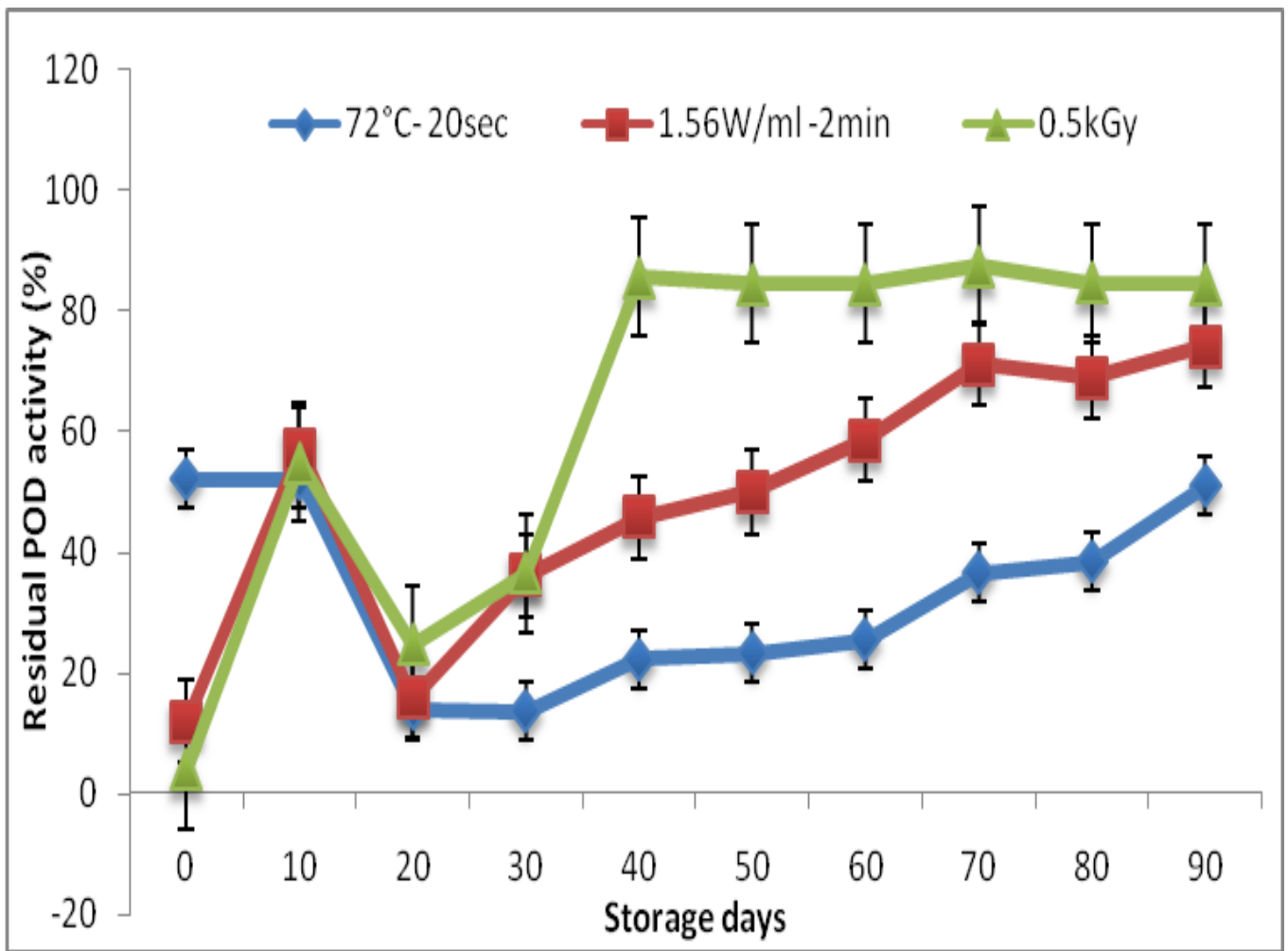


Fig.3 Effect of pasteurization methods on microbial load (log cfu/ml) during storage at $4 \pm 2{ }^{\circ} \mathrm{C}$

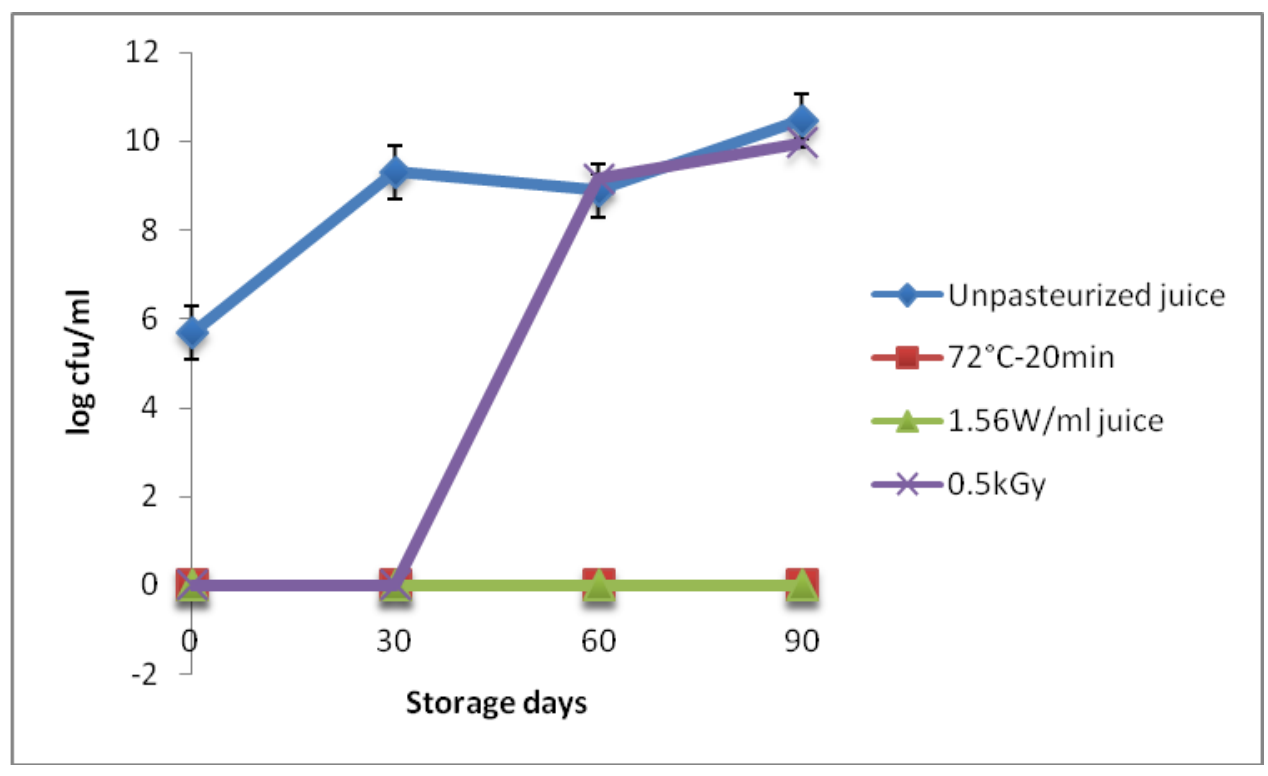

Fig.4 Effect pasteurization methods on sensory evaluation (overall acceptability) during storage at $4 \pm 2{ }^{\circ} \mathrm{C}$

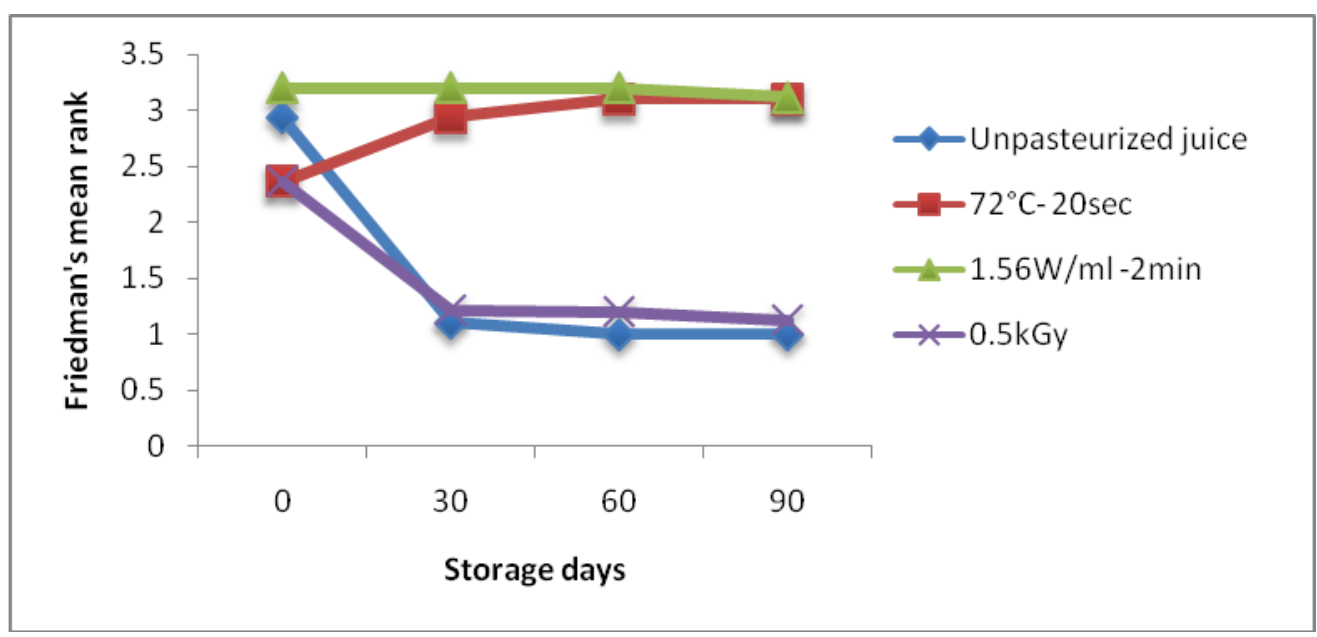

Initially irradiation showed maximum efficiency in inactivating the PPO. But, unfortunately the effect remained only for maximum 10 days. There was a sudden increase in the activity to $54.81 \%$ as per the $10^{\text {th }}$ day's observation. Irradiated sample remained satisfactory for a period of $30^{\text {th }}$ day. Peroxidases (POD) influence both colour and flavour of fruit juices. Activity of POD could be the reason behind the extreme off taste and flavour experienced during the sensory evaluation in the irradiated juice sample after one month period. This enzyme might be altered fresh watermelon flavor leaving behind an undesirable flavour. A study on enzyme inactivation in cantaloupe juice with the use of gamma irradiation suggested that, it is not a perfect method for inactivation of the PPO and POD (Wang et al., 2006). Contradictory to the result of PPO inactivation, the maximum efficiency in inactivating the POD was found in thermal 
pasteurized juice. At the end of storage period the maximum residual activity was $50.98 \%$, where it was 74.1 and $84.53 \%$ in microwave pasteurized and irradiated samples. Reports of Igual et al., (2014) was in accordance with the effectiveness of thermal pasteurization as compared to microwave pasteurization in grape fruit juice.

One recent report (Marszałek et al., 2015) clearly gave evidence that, only thermal pasteurization could able to inhibit the PPO and POD activities in strawberry puree in comparison with high pressure processing (HPP). However, in the present study thermal pasteurization was effective for reducing the only the activity of POD and not PPO.

The effect of microwave pasteurized watermelon juice was intermediate in reducing both $\mathrm{PPO}$ and $\mathrm{POD}$ activities. It showed only $31.36 \%$ and $12 \%$ initial PPO and POD activities. Faster inactivation of PPO and peroxidase POD was observed in microwave pasteurized coconut water than the conventional thermal process (Matsui et al., 2008). In comparison with conventional pasteurization, microwave heating was found effective in higher enzyme destruction the enzymes (Tajchakavit and Ramaswamy, 1997).

\section{Microbial evaluation}

The $\mathrm{pH}$ of fresh watermelon juice was $5.64 \pm 0.2$ and the prepared ready to serve juice after adding the acid regulator was $4.4 \pm 0.3$. Spoilage in the juice mainly resulted from the growth of acid tolerant bacteria, yeasts or molds that are sensitive to pasteurization. In this study, counts of total aerobic bacterial (TAB) and yeast and mould (Y\&M) were almost similar during the microbial enumeration. The initial mean populations of the TAB and Y\&M in fresh watermelon juice and the prepared ready to serve juice were $5.69 \pm 0.09, \quad 5.54 \pm 0.01$ and 5.68 \pm 0.03 ,
$5.53 \pm 0.01 \log \mathrm{cfu} / \mathrm{ml}$ respectively. The test for total coliforms was found to be negative. The effect of pasteurization methods on inhibiting the microbial population is represented in Figure 3. Thermal and microwave pasteurization was effective as to extend the shelf life of watermelon juice by inhibiting the growth of bacteria, yeast and mould. The juice remained free of contamination for the entire three months storage period. Similar to the observations of Naresh et al., (2015) in mango juice irradiation, the initial microbial load was significantly reduced by gamma irradiation at $0.5 \mathrm{kGy}$. But later an increase in the population was observed. Aligurchi et al., (2008) reported that the effect of irradiation in reducing the growth rate of bacteria and fungi of pomegranate juice was only for three days at $4{ }^{\circ} \mathrm{C}$. Result of the present study revealed that the irradiation could effectively control the microbial load in watermelon juice to the maximum extend of one month. Interestingly, thermal and microwave pasteurized juice were able to retain the quality of the juice over the entire storage period $(<1 \log$ cfu $\mathrm{ml}-1$ ). The obtained result was in agreement with Diaz and Aguayo (2013) who reported that the complete inactivation of microbial population in thermally pasteurized watermelon juice. Microwave treatment widely used in milk pasteurization because of its effectiveness in reducing thermal exposure to inactivate pathogenic while maintaining high quality. The internal components of the microbial cells disrupt due to the coupling of electromagnetic energy with critical molecules such as protein or DNA.

Even at higher microbial inoculums, mild microwave treatment could able to reduce more than 5-log (Geveke and Brunkhorst, 2004). Canumir et al., (2002) observed a 2-4 log reduction of total coliforms in apple juice depending on the power level (270-900 W) and time (40, 50, 60 and 90s). 


\section{Sensory evaluation}

The effect of pasteurization on sensory notes with respect to overall acceptability of the sensory parameters like appearance, colour, flavour and taste was evaluated. The trend in overall acceptability is shown in Figure 4. Panellists could not found any significant difference in appearance, flavour and taste immediately after different pasteurization. But it showed a clear difference in overall acceptability. Unlike other reports of fruit juice irradiation, the irradiated watermelon juice sample obtained the lowest score. Naresh et al., (2015) did not find any significant changes in the sensory scores of irradiated mango juice at 1,3 and $5 \mathrm{kGy}$. Degradation of colour was observed for all the treatments except the irradiated juice during the entire storage. In fact, the irradiated juice turned darker in colour. This could be directly linked to the improved lycopene content after irradiation. Regarding the flavour of the juice, immediately after pasteurization all the treatments except the unpasteurized juice showed similar flavour. Presence of off flavour was detected from irradiated juice sample on the $30^{\text {th }}$ day of evaluation. The panellists preferred microwave pasteurized juice for the taste properties followed by thermal pasteurized juice.

The most acceptable overall quality characteristics in ready to serve watermelon juice were found in microwave pasteurized juice $(1.56 \mathrm{~W} / \mathrm{ml}$ juice) with a mean Firedman's score of 3.5 followed by the thermal pasteurization (3.3). During the storage study of centrifuged watermelon juice Diaz and Aguayo (2013) observed a marked reduction in colour and flavour in during the $10^{\text {th }}$ day itself. In that case, the result obtained from the present study concludes that microwave pasteurization is a reliable method in comparison with the conventional thermal pasteurization in retaining especially the flavour and colour of the juice while reducing the microbial population.

\section{References}

Aguilo-Aguayo I, Montero-Calderon M, Soliva-Fortuny $\mathrm{R}$ and Martin-Belloso O. 2010. Changes on flavor compounds throughout cold storage of watermelon juice processed by high-intensity pulsed electric fields of heat. Journal of Food Engineering. 100: 43-9.

Al-Hilphy A R S and Ali H I. 2014. Milk Flash Pasteurization by the Microwave and Study its Chemical, Microbiological and Thermo Physical Characteristics. Food Processing and Technology. 4:7

Alighourchi H, Barzegar M, Sahari M A and Abbasi, S. 2014. The effects of sonication and gamma irradiation on the inactivation of Escherichia coli and Saccharomyces cerevisiae in pomegranate juice. Iranian Journal of Microbiology. 6(1): 51-58

Alighourchi H, Barzegar $M$ and Abbasi S. 2008. Effect of gamma irradiation on the stability of anthocyanins and shelflife of various pomegranate juices. Food Chemistry. 110: 1036-1040.

AOAC. 2002. Official methods of analysis (17th ed.). The Association of official analytical chemists. Gaithersburg, MD, USA

Canumir $\mathbf{J}$ A, Celis $\mathbf{J}$ E, Bruijn $\mathbf{J}$ and Vidal LV. 2001. Pasteurisation of apple juice by using microwaves. LebensmittelWissenschaft and Technologie. 35:38992.

Chiu C P, Tateishi K, Kosikowski F V and Ambruster G. 1984. Microwave treatment of pasteurized milk. Journal of Microwave Power. 19 (4):269- 272.

Diaz M P and Aguayo E. 2013. Influence of acidification, 
centrifugation and storage time and temperature on watermelon juice quality. Journal of Science Food and Agriculture.93: 3863-9

Diaz J, Bernal A, Pomar F and Marino F. 2001. Induction of shikimate dehydrogenase and peroxidase in pepper (Capsicum annuum L.) seedings in response to copper stress and its relation to linification. Plant Science. 161: 179- 88 .

Eissa H A, Shaheen M S and Botros H W. 2014. Impact of $\gamma$-irradiation on aroma flavour, bio-active constituents and quality attributes of water melon juice. Journal of Plant Pathology and Microbiology. 5(2):1-9

Ertugay M F, Baslar M and Ortak F. 2013. Effect of pulsed electric field treatment on polyphenol oxidase, total phenolic compounds, and microbial growth of apple juice. Turkish Journal of Agriculture and Forestry. 37: 772-78

Food and Drug Administration (FDA). 2004. Guidance for industry: Juice HACCP hazards and controls guidance first edition; final guidance. http://www.fda.gov/Food/Guidance ComplianceRegulatoryInformation/Gui danceDocuments/Juice/ucm072557.htm

Geveke D J and Brunkhorst C. 2004. Inactivation of Escherichia coli in apple juice by Radio Frequency Electric Fields. Journal of Food Science. 69(3):134-8.

Hanotel, L, Fleuriet A and Boisseau, P. 1995.Biochemical changes involved in browning of gamma-irradiated cut witloof chicory. Postharvest biology and technology 5(3):199-10

Igual M, Garcia-Martinez E, Camacho M M and Martinez-Navarrete N. 2010. Effect of thermal treatment and storage on the stability of organic acids and the functional value of grapefruit juice. Food Chemistry. 118: 291-9.
Kunitake M T, Ditchfield C, Silva C O and Petrus R R. 2014. Effect of pasteurization temperature on sensory stability of an acidified sugarcane juice beverage. Journal of Food Processing and Technology. 5:12-3.

Liu Y, Hu X, Zhao X and Song H. 2012. Effect of high pressure carbon dioxide and mild heat treatment on overall quality parameters of watermelon juice. Innovative Food Science and Emerging Technologies 13: 112-19.

Lotfian, F., Khaneghah A M., Ghaderifarah, M., Jahed, E., Atlassi V. 2013. Effect of electromagnetic waves (microwave) on microbial load and shelf life of liquid egg white electromagnetic waves (microwave) on microbial load and shelf life of liquid egg whites. Journal of Applied Science and Agriculture. 8(7): 1431-7

Marszałek K, Mitek M, Skąpska, S. 2015. The effect of thermal pasteurization and high pressure processing at cold and mild temperatures on the chemical composition, microbial and enzyme activity in strawberry purée. Innovative Food Science and Emerging Technologies. 27:48-56

Math, R.G., Nagender, A., Sameera, N. and Satyanarayana, A. 2014. Continuous microwave processing and preservation of acidic and non-acidic juice blends. International Journal of Agricultural Food Science and Technology. 5(2): 8190.

Matsui K N, Gut J A W, Oliveira P V and Tadini CC de. 2008 Inactivation kinetics of polyphenol oxidase and peroxidase in green coconut water by microwave processing, Journal of Food Engineering. 88: 169-76.

Naresh K, Varakumar S, Prasad Shekhar Variyar P S, Sharma A and Reddy O V S 2014. Enhancing antioxidant activity, microbial and sensory quality of mango 
(Mangifera indica L.) juice by $\gamma$ irradiation and its in vitro radioprotective potential. Journal of Food Science and Technology 1-7

Nikdel S and MacKellar A. 1992. Microwave system for continuous pasteurization of orange juice. Proceedings of Florida State Horticultural Society. 105: 10810.

Perkins-Veazie P and Collins J K. 2004). Flesh quality and lycopene stability of fresh-cut watermelon. Postharvest Biol Tech. 31:159-66.

Ranganna, S. 2002. Analysis and quality control for fruit and vegetable product. Third Ed. Tata McGraw Hill Pub. New Delhi.

Rasooly R, Hernlem B, He X and Friedman M. 2014. Microwave Heating Inactivates Shiga Toxin (Stx2) in Reconstituted Fat-Free Milk and Adversely Affects the Nutritional Value of Cell Culture Medium. Journal of Agricultural and Food Chemistry. 62(14). 52-7

Rodrigo D, Cortes C, Clynen E, Schoofs L, Van Loey A and Hendrickx M. 2006. Thermal and high-pressure stability of purified polygalacturonase and pectin methylesterase from four different tomato processing varieties. Food Research International. 39: 440-8.

Soliva R C, Elez P, Sebastian M and Martin
O. 2001. Evaluation of browning effect on avocado puree preserved by combined methods. Innovative Food Science and Emerging Technology. 1: 261-8.

Tajchakavit S and Ramaswamy H S. 1997. Continuous flow microwave inactivation kinetics of pectin methylesterase in orange juice. Journal of Food Processing and Preservation. 21:365-8.

Terefe N S, Yang Y H, Knoerze K, Buckow $R$ and Versteeg C. 2010. High pressure and thermal inactivation kinetics of polyphenol oxidase and peroxidase in strawberry puree. Innovative Food Science and Emerging Technologies. 11(1): 52-60

Villamiel M, Corzo N, Martinez-Castrob I and O1anoa A. 1996. Chemical changes during microwave treatment of milk. Food Chemistry. 56(4):385-8.

Wang, Z, Yongkun M, Zhao G, Liao X, Chen $\mathrm{F}$, Wu J, Chen J and $\mathrm{Hu}$ X. 2006. Influence of irradiation on enzyme, microorganism, and flavor of cantaloupe (Cucumis melo L.) Juice. Journal of Food Science. 71 (6):215-20.

WHO. 1999. High-dose irradiation: Wholesomeness of food irradiated with doses above $10 \mathrm{kGy}$, Report of a joint FAO/IAEA/WHO study group. WHO technical Report Series 890. Geneva.

\section{How to cite this article:}

Shameena Beegum, V.R. Sagar, Abhijit Kar, Eldho Varghese, Surender Singh, M. Neema, Krishna Prakash and Aparna V. 2019. Effect of Pasteurization Methods on Enzyme Activities, Microbial and Sensory Evaluations in Ready to Serve Watermelon Juice (Citrullus lanatus). Int.J.Curr.Microbiol.App.Sci. 8(06): 2708-2717. doi: https://doi.org/10.20546/ijcmas.2019.806.325 